\title{
Inhalt, Vol. 4, No. 6, 1981
}

Zeitschnft für Krebsforschung u. -behandlung unter Fortführung der »österreichischen Zeitschrift für Onkologie«

Band 4, Nummer 6, Dezember 1981

Inhalt

Contents

295

Impressum.

von Hey den, H. W.; Beyer, J.-H.; Matthaei, A.;

Nagel, G. A. und Schroder, M., Göttingen

Zwischenauswertung einer Chemotherapie-Studie an

Patienten mit Plattenepithelkarzinomen im Kopf-Hals-

Bereich. Vergleich zweier Therapieregime: Cis-Diamino-

dichloroplatinum (II) (cis-DDP) und Bleomycin gegen

Methotrexat und Vindesin 296

Hammer, J.; Kratzer, H.; Denz, H.; Aigner, K.;

Schindl, R.; Michlmayr, G. und Wachtler, F. ,

LinzlAustria

Kombinierte Chemo- und Radiotherapie bei kleínzelligen

Bronchuskarzinomen 300

Weber, W. und Obrecht, J. P., Basel/Schweiz Chemotherapie des fortgeschrittenen

Magenkarzinoms . 304

Sonderbände 307

Diehl, V., Hannover

Bericht über klinische Studien mit hochdosierter Metho-

trexat-Therapie in Europa (Nicht EORTC-Studien) ... 308

Hinweise für Autoren 319

Scherer, E. und Schultz, U. , Essen

Möglichkeiten und Grenzen der Strahlentherapie bei

Geschwülsten der vorderen Schädelgrube 322

Busse, E.; Helmholz, M. und Magdon, E., DDR-Berlin Altersbedingte Veränderungen des

cAMP- und Prosta-glandingehaltes im Gehirn und in den Lymphozyten von spontan

mammakarzinombildenden C3H-Mäusen .... 328

Urban, Ch.; Hackl, A.; Kurz, R.; Becker, H. und

Mutz, I. D., GrazlAustria

Probleme des Morbus Hodgkin im Kindesalter

Buchbesprechungen 342

Onkologie-Mitteilungen 
von Hey den, H. W.; Beyer, J.-H.; Matthaei, A.;

Nagel, G. A., and Schroder, M., Göttingen

Preliminary Results of a Chemotherapy Trial for Squa-

mous Cell Carcinoma of Head and Neck Region. Compar

ison of Two Regimes: Cis-Dichlorodiammineplatinum

(II) (Cis-DDP) and Bleomycin Against Methotrexate and

Vindesine 296

Hammer, J.; Kratzer, H.; Denz, H.; Aigner, K.; Schindl, R.; Michlmayr, G., and Wachtler, F., LinzlAustria

Combined Chemo-Radiotherapy of Small Cell Broncho-

genie Carcinoma 300

Weber, W. and Obrecht, J. P., Basel/Schweiz

Chemotherapy of Advanced Gastric Cancer 304

Special Editions 307

Diehl, V., Hannover

Report on Various Clinical Studies on High Dose Metho

trexate in Europe (Non-EORTC) 308

Instructions for Authors 319

Scherer, E. and Schultz, U. , Essen

Possibilities and Borders in Radiation Therapy of Ante

rior Cranial Fossa Tumors 322

Busse, E.; Helmholz, M., and Magdon, E., DDR-Berlin

Age-caused Changes in the Level of cAMP and Prosta-

glandin in the Brain and Lymphocytes of Spontaneously

Mammacarcinoma Producing C3H Mice 328

Urban, Ch., Hackl, A.; Kurz, R.; Becker, H., and

Mutz, I. D., Grazl Austria

Hodgkin's Disease - Problems in Childhood 331

Book Reviews 342

Oncology-Informations 343

Bibliographischer Hinweis: Inhaltsverzeichmsse dieser Zeitschrift erscheinen regelmäßig in current contents ${ }^{\circledR}$ sowie in anderen bibliographischen Diensten. 